\title{
Sorting and Recycling of Lightweight Packaging in Germany - Climate Impacts and Options for Increasing Circularity Using Tracer-Based-Sorting
}

\author{
Anina Kusch ${ }^{1} \cdot$ Johannes Gasde $^{1} \cdot$ Carolin Deregowski $^{1} \cdot$ Jörg Woidasky $^{1} \cdot$ Claus Lang-Koetz $^{1}$ (D) Tobias Viere $^{1}$
}

Received: 18 February 2021 / Revised: 12 April 2021 / Accepted: 2 May 2021 / Published online: 28 June 2021

(c) The Author(s) 2021

\begin{abstract}
This paper elaborates an energy and material flow model for conventional lightweight packaging sorting and recycling in Germany based on literature analysis and information provided by industry experts. The model is used to determine specific energy and material demands of particular lightweight packaging fractions and their respective climate impacts. Fluorescentbased identification techniques, tracer-based-sorting in particular, are assessed as an option to increase material circularity due to improved sorting and recycling accuracy. In comparison to primary production of lightweight packaging, conventional sorting and recycling saves $565 \mathrm{~kg} \mathrm{CO}_{2}$-eq./Mg of input sorting. A total of four implementation scenarios are considered, reflecting the percentage of mixed plastics and residuals that can be mechanically processed through improved sorting (10\%, $50 \%, 90 \%$ and 100\%). Using tracer-based-sorting, these savings increase from 578 up to $1227 \mathrm{~kg} \mathrm{CO}_{2}$-eq/Mg depending on implementation scenario. This paper concludes that tracer-based-sorting can contribute to an environmentally benign circular economy by yielding high-quality regranulates, which are capable of substituting more carbon-intensive primary production of lightweight packaging.
\end{abstract}

Keywords Sorting and recycling · Lightweight packaging · Tracer-based-sorting · Carbon footprint · Circular economy · Plastics recycling

\section{Introduction}

The packaging industry is the most important single polymer consuming industrial sector in Europe (PlasticsEurope AISBL; EPRO 2018). The increasing use of this material is leading to a global problem - plastics in the environment - with consequences that are still difficult to assess (Coelho et al. 2011; Jambeck et al. 2015). A sustainable circular economy is seen as a solution to reduce both, the production of plastics based on raw materials and the disposal and littering of used plastic products. It has become part of national and international policies and legislation (see, e.g. the German Recycling Law (Kreislaufwirtschaftsgesetz 2012) and the European Action Plan for the Circular

Claus Lang-Koetz

claus.lang-koetz@hs-pforzheim.de

1 Institute for Industrial Ecology (INEC), Pforzheim

University of Applied Sciences, Tiefenbronner Str. 65,

75175 Pforzheim, Germany
Economy (European Commission 2015, 2020). Such circularity requires efficient material flows and environmental sustainability throughout the whole life cycle (Geueke et al. 2018).

A mass increase in plastic waste (Destatis 2020) and a further increase in statutory recycling rates all over Europe including Germany (German Packaging Law 2017) are forcing waste management systems to continuously increase recycling activities. Since the beginning of 2019, the German Packaging Act stipulates new recycling quotas for plastic packaging: a quota of $63 \%$ must be met by 2022 (Birnstengel et al. 2018).

Today, plastic packaging materials are separated in several stages of large sorting plants by mechanical separation steps such as classification and sorting and eventually identified by near-infrared spectroscopy (NIR). Modern sorting plants use up to about fifty individual NIR sorters, which 
are capable to separate the plastic packaging into the main polymers HDPE, LDPE, PP, PET and PS. ${ }^{1}$ A large, inferior mixed plastic fraction remains, which at best is recycled in thick-walled products. In addition, a sorting residue of at least $20 \%$ arises which has to be incinerated (MEILO - MEILO Gesellschaft zur Rückgewinnung sortierter Werkstoffe mbH \& Co. KG 2020). In the industry, sorting is optimized according to sorting fraction specifications based on typical waste management parameters. They generally allow for $10 \%$ foreign content in the products and do not go beyond a rough polymer specification (DSD - Duales System Deutschland $\mathrm{GmbH}$ 2020). The current business model for the operation of sorting plants leads to an overload of the separation technology. Plants are operated with significantly higher throughput than specified, resulting in low sorting quality. There is no incentive for sorters to reduce the foreign content in the recyclate below specification limits and therefore sorting product qualities fall short of what is technically possible. However, even compliance or overcompliance with current sorting specifications is not sufficient for highquality material recycling of plastics (Roosen et al. 2020) as this requires a separation according to plastic types (e.g. monomodal HDPE).

There are three main ways to recycle pre-sorted lightweight packaging (LWP): energy recovery, feedstock recycling and mechanical recycling. In energy recovery, waste is incinerated, and the resulting energy can then be used in the form of heat and electricity (Grigore 2017; Martens and Goldmann 2016; Ragaert et al. 2017). In feedstock recycling, polymer chains are modified, shortened and in some cases degraded into their initial materials or chemical base compounds. This is done by processes such as pyrolysis, a thermal separation process or solvolysis processes. In mechanical recycling, the polymer chains will be preserved and processed into secondary raw materials (Ignatyev et al. 2014). The resulting granulate can be reused and therefore replaces primary raw materials, often designated as "regranulate" (Hellerich et al. 2010).

Basic mechanical recycling involves sorting LWP according to its inherent material properties (shape, size, density, colour and chemical composition). The packaging waste stream is cascaded through various separation processes and is typically sorted into 16-20 different fractions. Sensorbased systems support the detection, especially of main polymer fractions (Ignatyev et al. 2014; Martens and Goldmann 2016; Shen and Worrell 2014). Compressed into bales, the packaging is thereafter sent to its respective recycling routes. For mechanical recycling, packaging is usually re-sorted and

\footnotetext{
${ }^{1} \mathrm{HDPE}=$ high density polyethylene; LDPE = low density polyethylene; $\mathrm{PP}=$ polypropylene; $\mathrm{PET}=$ polyethylenterephthalat; $\mathrm{PS}=$ polystyrene.
}

washed, and impurities are removed. An extruder is used to produce granules from the recycled material as an industry commodity (ITAD 2015; Martens and Goldmann 2016). In summary, there are different recycling techniques, varying the optimal method for each polymer type. Based on the recycling hierarchy, incineration is at the bottom with a recycling efficiency of $0 \%$. Therefore, the goal is to recycle mechanically in order to replace a linear economy with a circular economy (Schwarz et al. 2021).

High-quality material recycling can be achieved by selecting or combining known techniques such as mechanical sorting and NIR separation with new methods of image recognition and targeted labelling using fluorescent tracers in order to identify and sort complex packaging (Kreibe et al. 2017; Moser et al. 2016). There are several techniques to improve the identification of materials with fluorescent substances. One particularly efficient and robust fluorescence-based technique for material identification is tracer-based-sorting (Arenas-Vivo et al. 2017; Brunner et al. 2015; Maris et al. 2012; Woidasky et al. 2020b). The tracer-based-sorting (TBS) technology allows high-quality plastics recycling and the return of packaging materials to the material cycle (Gasde et al. 2021; Woidasky et al. 2020a, 2020b, 2020c). TBS enables material identification independent of the physical properties of packaging and can be applied to all types of packaging. An inorganic fluorescent tracer substance is placed on products, such as host oxide crystals doped with rare earth elements (ytterbium erbium, holmium or thulium) serving as sensitizers and activator substances for photoluminescence (Woidasky et al 2020a).

It can be added directly to the packaging object (as additive in compounding, in a coating or in ink of the printed label) and remains invisible under normal conditions. Using infrared irradiation, the tracer substance is excited and reemits specific wavelength signals within milliseconds. For the purpose of an efficient and reliable packaging material identification, small quantities of the fluorescent tracer are applied within the printing ink on the packaging label. Combinations of several tracer substances can form "codes" and serve as identification for sorting according to type (Woidasky et al. 2020a, 2020c). The technology was developed and adapted for the application in plastics packaging recycling in the research project "MaReK - Marker based sorting and recycling system for plastic packaging". ${ }^{2}$ TBS has been demonstrated in a pilot plant for packaging sorting but has not been introduced into the market, yet.

Published life cycle assessment studies of plastics recycling, mainly of beverage packaging, typically do not show a detailed analysis of the individual process steps of sorting

\footnotetext{
2 Project duration: July 2017-December 2020; for more information, see http://www.hs-pforzheim.de/marek.
} 
Fig. 1 Sorting and recycling system overview

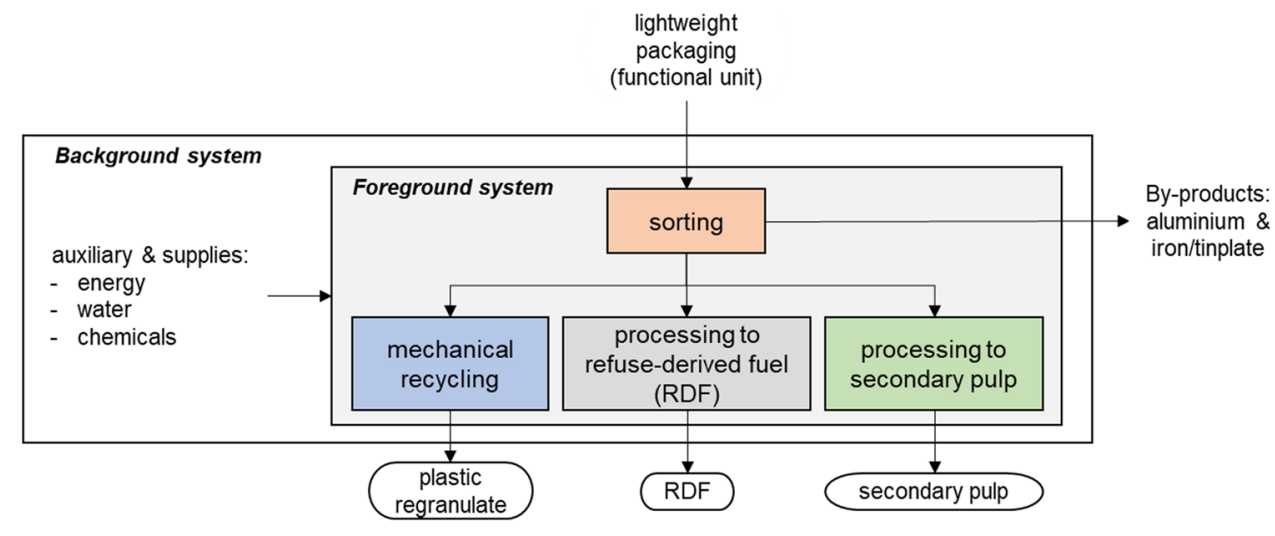

and recycling, nor the potential of future innovative technologies (Detzel et al. 2016; Detzel and Böß 2006; Kauertz et al. 2011; Schonert et al. 2002). Recent LCA research by Schwarz et al. offers a systematic comparison of different recycling pathways of plastics and conclude that "optimal environmental performance of recycling can only be obtained where pre-treatment is improved in line with the most suitable recycling method for a polymer" (Schwarz et al. 2021). TBS offers one technical solution to improve pre-treatment of polymers. In order to assess the economic and environmental potential of TBS, the authors of this article are addressing this current research gap by conducting a detailed carbon footprint assessment of conventional LWP sorting and recycling and by evaluating the environmental and circular economy consequences of modifying it using TBS scenarios.

\section{Method}

\section{Material and Energy Flow-Based Carbon Footprint}

Defined by the ISO EN 14040 and 14044 standards, life cycle assessment (LCA) is a method for analysing the potential environmental impacts of products and services. The standards specify the methodological procedure as well as the principles and characteristics of an LCA study (DIN EN ISO 14040 2009; Hauschild and Huijbregts 2015; Klöpffer and Grahl 2009). A carbon footprint is based on the methodological approach and the principles of life cycle assessment and limits the evaluation on the basis of one environmental impact category, climate change (DIN EN ISO 14067 2019). Hence carbon footprints account for greenhouse gases caused by products and processes, which contribute to global temperature increase and its consequences. Climate change measured as global warming potential in $\mathrm{kg}$ carbon dioxide equivalents ( $\mathrm{kg} \mathrm{CO}_{2}$-eq.) is a globally accepted and highly reliable environmental impact category (European
Commission et al. 2012; IPCC - Intergovernmental Panel on Climate Change 2015).

LCA and carbon footprints studies require data on material and energy flows of the systems under examination. The data collection of this study is based on literature research and interviews with experts from German waste management industry. Data from state-of-the-art sorting and recycling plants in Germany is used to calculate process-specific material and energy flows. Individual sorting processes are modelled using operating data from the LWP sorting plant MEILO in Gernsheim (data from 2019). For the modelling of different recycling paths, practical data from expert interviews, including with a plastics recycler, are used to obtain a realistic picture of the current state of the art as well as further literature. The development of the energy and material flow model for mechanical recycling is based on data from several expert interviews, for example, with the plastic recycler mtm plastics GmbH (Deregowski 2020). The data was validated by industry-specific experts and the German Association for Secondary Raw Materials and Waste Disposal (Bundesverband für Sekundärrohstoffe und Entsorgung e.V.) (bvse). To complete modelling of all scenarios, missing data is supplemented by information from the literature and realistic estimates and assumptions (Kusch 2020). For the modelling of the TBS sorting aggregates, the project partner Polysecure used a pilot plant for initial estimations (data from 2020). Upstream processes for supplying electricity, water or required chemicals such as sodium hydroxide solution, aluminium sulfate and polyaluminium chloride are derived from the ecoinvent database 3.6 (ecoinvent 2020; Wernet et al. 2016). The whole system including upstream processes has been modelled using the LCA software Umberto LCA + (ifu Institut für Umweltinformatik Hamburg GmbH 2020).

The goal of this study is to assess the carbon footprint of the conventional sorting and recycling system of post-consumer LWP in Germany. Based on this, the effects of TBS supported sorting are visualised and quantitatively evaluated and compared with the conventional system. Figure 1 defines 
the system boundaries and provides an overview of the main system for all scenarios under assessment. The foreground system, i.e. the core of the assessment using primary data, includes the sorting of the LWPs as well as three recycling paths. Well-sorted plastic fractions can be recycled mechanically, while mixed plastics and other residues are processed into refuse-derived fuel (RDF) and paper/cardboard fractions are processed into secondary pulp. The recycling of aluminium and iron fractions is not further assessed as this study focuses on plastics recycling. The background system includes the prechains of auxiliaries and supplies, e.g. the generation of required electric energy.

On this basis, three scenarios were modelled and evaluated: the conventional sorting and recycling system, the consideration of a "TBS light" scenario and the integration of a "TBS complete" scenario (Gasde et al. 2021; Woidasky et al. 2020a). As the LCA work was carried out in parallel to the TBS technical development, the conventional sorting and recycling was chosen as a reference case, reflecting best industrial practices as identified in modern LWP sorting plants, and deviations from this reference case were estimated based on the current stage of development of the TBS technology with its current technology readiness levels (TRL). The scenarios chosen were:

- "TBS light" as an extension of existing processes for LWP sorting, describing an additional sorting stage for the plastic fractions PET, PP and PE added to the conventional LWP sorting process. This scenario is particularly suitable for implementation in existing plants and complex sorting systems. The previous sorting process remains completely unchanged, and TBS is used for resorting in order to clearly identify and sort out, for example, multilayer packaging. The TRL of this approach at the time of assessment was at 4 (small-scale prototype in lab scale).

- In contrast, "TBS complete" is intended to replace main sorting processes of the conventional system. The aim of "TBS complete" is to sort into sub-fractions and additionally new fractions, in particular plastics, resulting in an increase in the quality and purity of the recyclate. This also helps to identify the mixed plastics and residues that have been difficult to sort previously, resulting in a larger recycling percentage. The TRL of this approach at the time of assessment was at 2-3 (technology was formulated, first lab tests were made). As TRL was low, for "TBS complete", assumption-based sub-scenarios were defined to consider different increase rates of mechanical recycling, i.e. the percentage of mixed plastics and other materials that were previously processed into RDF and can now be separated for mechanical recycling into regranulate $(10 \%, 50 \%, 90 \%$ and $100 \%)$. These percentage figures can be considered as the product of the prob-
Table 1 Fractions of LWP waste adapted from Christiani 2017; Woidasky et al. 2020b

\begin{tabular}{ll}
\hline Input fraction & $\begin{array}{l}\text { Distribution of } \\
\text { the input quantity } \\
{[\mathrm{Wt} . \text {-\%] }}\end{array}$ \\
\hline LDPE & 6.3 \\
HDPE & 3.7 \\
PP & 11.3 \\
Mixed polyolefins (MPO) (PE and PP) & 3.5 \\
PS & 2.8 \\
PET bottles & 5.6 \\
Mixed plastics (MP)/other PET & 3.4 \\
Mixed plastics (MP)/other plastic packaging & 3.8 \\
MP/other plastic non-packaging & 3.9 \\
Paper, carton, cardboard (PCC) & 5.1 \\
liquid carton (LC) & 18.0 \\
Aluminium-containing packaging (ACP) & 2.5 \\
Aluminium & 2.1 \\
Iron/tinplate & 9.2 \\
Residues/Others & 18.8 \\
\hline
\end{tabular}

ability of detection by the TBS approach and the mechanical ability of the sorting system to separate the particle from the material stream. Even current, very high detection rates of up to $100 \%$ which were shown in experiments may not necessary result in a complete separation, as, e.g. cylindrical geometries in current sorters based on pressurized air nozzle technology often are not separated properly. Consequently, future developments of TBS complete might not only provide identification means, but also address the separation mechanism applied.

The system's functional unit was defined as sorting and recycling of $1 \mathrm{Mg}$ (one metric ton) of average LWP waste. The fractions of this average LWP waste flow as depicted in Table 1 are defined by the German LWP mix (Christiani 2017) and further detailed by a LWP analysis, which differentiated and examined packaging from 35 German households according to several sorting criteria (Woidasky et al. 2020b).

A material and energy flow model of all relevant sorting and recycling processes has been developed, which includes the average LWP waste flow and its single fractions. Upstream processes for supplying electricity, water or required chemicals such as sodium hydroxide solution, aluminium sulfate and polyaluminium chloride have been derived from the ecoinvent database 3.6 (ecoinvent 2020; Wernet et al. 2016). The required tracer substance for TBS is not included in the carbon footprint due to the small quantity required in relation to the reference flow (Kälber 2019). The whole system including upstream processes has been 
Table 2 Credits of all scenarios own calculation based on Christiani et al. 2001; Dehoust and Christiani 2012; Kauertz et al. 2011; Wernet et al. 2016

\begin{tabular}{|c|c|c|c|c|c|}
\hline Output fraction & Ecoinvent material & $\begin{array}{l}\text { Climate impact of } \\
\text { primary product }[\mathrm{kg} \\
\left.\mathrm{CO}_{2}-\mathrm{eq} / \mathrm{kg}\right]\end{array}$ & SF & Credit & Use in scenarios \\
\hline LDPE regranulate & $\begin{array}{l}\text { Polyethylene, low density, } \\
\text { granulate }\end{array}$ & 2.49 & 0.90 & 2.24 & All \\
\hline HDPE food regranulate & \multirow{2}{*}{$\begin{array}{l}\text { Polyethylene, high density, } \\
\text { granulate }\end{array}$} & 2.33 & 1.00 & 2.33 & "TBS light" \& "TBS complete" \\
\hline HDPE regranulate & & 2.33 & 0.90 & 2.10 & all \\
\hline PP food regranulate & \multirow[t]{2}{*}{ Polypropylene granulate } & 2.29 & 1.00 & 2.29 & "TBS light" \& "TBS complete" \\
\hline PP regranulate & & 2.29 & 0.90 & 2.06 & all \\
\hline MPO regranulate & $\begin{array}{l}\text { Average value of } \mathrm{PE} \text { and } \mathrm{PP} \\
\text { regranulate }\end{array}$ & 2.31 & 0.70 & 1.62 & all \\
\hline PS food regranulate & \multirow[t]{2}{*}{ Polystyrene expandable } & 3.63 & 1.00 & 3.63 & "TBS complete" \\
\hline PS regranulate & & 3.63 & 0.90 & 3.27 & all \\
\hline PET bottles food regranulate & \multirow{2}{*}{$\begin{array}{l}\text { Polyethylene terephthalate granu- } \\
\text { late, bottle grade }\end{array}$} & 2.91 & 1.00 & 2.91 & "TBS light" \& "TBS complete" \\
\hline PET bottles regranulate & & 2.91 & 1.00 & 2.91 & All \\
\hline MP food regranulate & \multirow[b]{2}{*}{$\begin{array}{l}\text { Average climate impact of the } \\
\text { plastics "PE" (29\%), "PP" } \\
\text { (41\%), "PET bottles" (18\%) } \\
\text { and "PS" (12\%) Klicken } \\
\text { oder tippen Sie hier, um Text } \\
\text { einzugeben }\end{array}$} & 3.30 & 1.00 & 3.30 & "TBS complete" \\
\hline MP regranulate & & 3.30 & 0.90 & 2.97 & "TBS complete" \\
\hline Secondary pulp & Thermo-mechanical pulp & 1.58 & 0.50 & 0.79 & All \\
\hline Others food regranulate & \multirow{2}{*}{$\begin{array}{l}\text { Average climate impact of the } \\
\text { plastics "PE" }(29 \%), \text { "PP" } \\
\text { (41\%), "PET bottles" (18\%) and } \\
\text { "PS" }(12 \%)^{\mathrm{a}}\end{array}$} & 3.30 & 1.00 & 3.30 & "TBS complete" \\
\hline Others regranulate & & 3.30 & 0.90 & 2.97 & "TBS complete" \\
\hline Refuse-derived fuel (RDF) & Hard coal & 0.41 & 1.00 & 0.41 & All \\
\hline
\end{tabular}

modelled using the LCA software Umberto LCA + (ifu Institut für Umweltinformatik Hamburg GmbH 2020).

All material and energy flows within the model follow ecoinvent database nomenclature to enable direct assessment of life cycle impacts. The climate impact has been computed as Global Warming Potential over 100 years measured in kilograms of $\mathrm{CO}_{2}$ equivalents $\left(\mathrm{kg} \mathrm{CO}_{2}\right.$-eq).

\section{Credits}

Sorting and recycling results in recyclates that substitute raw materials that would otherwise have to be newly produced. To account for the environmental benefits of this secondary material, system extension is a widely used approach in recycling life cycle assessments (Finnveden 1999; Heijungs and Guinée 2007; Suski and Wiesen 2016). Reference systems have been created for all output fractions of the recycling process, and the expenditure is offset by credits for total savings. Each reference system subsequently receives a credit, allowing these impacts to be compared with the impact of sorting and recycling (Klöpffer and Grahl 2009). Credits are allocated individually according to the output fraction and are calculated as the product of the environmental impact of the replaceable primary product and a substitution factor (SF). The SF reflects the extent to which a secondary product can replace a primary product, since in most cases the material properties are not the same due to quality losses and depend on the type of material (Christiani et al. 2001). The better the output quality, the higher the factor and the more primary material can be substituted, and resources saved. Data sets from the ecoinvent database formed the basis for the impacts of comparable primary products. Table 2 summarizes all credits and related assumptions.

These credits were directly modelled in Umberto which enables a quick evaluation of the results. Modelling in Umberto also requires the definition of internal allocation rules for each process with multiple outputs. Material types must be defined for self-created materials which are distinguished between "Good", "Bad" and "Neutral". Depending on the type of material, the flow is classified as expenditure or income and is particularly important in multi-output processes, for allocation into product and by-product. This classification is essential for the further allocation within the modelled processes. On the basis of the allocation, the expenditures in the process were then allocated to the various products, resulting in the final calculation of the climate impacts. User-defined 
allocation rules were defined for each process. Resources, e.g. energy, were physically allocated to the input fractions, while the expenses for the individual fractions were set using a user-defined allocation factor (ifu Institut für Umweltinformatik Hamburg GmbH 2017).

\section{Circularity}

Within a circular economy, all non-renewable material is supposed to be maintained within the technosphere as long as possible in order to minimize resource extraction, waste disposal and associated ecological impacts. There is a huge variety of approaches how to increase material circularity, e.g. reuse, remanufacturing or sharing strategies (Stahel 2016). Given that this paper has a clear end-of-life focus, the obvious approach to increase circularity is to enable high-quality recycling. A variety of indicators are available to measure circularity, and no consensus on the best metrics has been reached so far (Corona et al. 2019). In the specific case of LWP sorting and recycling, there are legal requirements for recycling rate, though, which can be considered as a basic circularity indicator.

The focus of this study is on recycling quota of plastics, which is required to be above $63 \%$ according to legislation (German Packaging Law 2017). The amount of plastic input defined in the reference flow is $44.3 \%$ of total input. For the calculation, the collection rate is taken into account, for which a pessimistic value of $60 \%$ is assumed (Bünemann et al. 2011; Urban and Halm 2012). In the following, two approaches for the calculation of RQ are pursued: inputbased (previous approach according to German Packaging Law 2017) and output-based. In the first approach, only the input mass to mechanical recycling is considered as input of recycling.

Input-based recycling quota (Destatis 2020):

$$
R Q_{\text {input }}=\frac{\text { input of all material recycling plants }}{\text { total mass of waste }} * 100
$$

However, this approach shows weaknesses in terms of the method of calculation. The reference basis is the input mass in the recycling process and the waste and losses resulting from the recycling process are thus completely neglected. As a result, a recalculation of the recycling quota is already being targeted by the European Parliament (European Parliament 2018), which is defining reference points for the future calculation (European Parliament 2018; European Union 2019) and, together with other stakeholders, requesting an outputoriented approach (PlasticsEurope AISBL 2019).

Output-based recycling quota (PlasticsEurope AISBL 2019):
$R Q_{\text {output }}=\frac{\text { output of all material recycling plants }}{\text { total mass of waste }} * 100$

For the conventional recycling and sorting system as well as for all TBS scenarios, $R Q_{\text {input }}$ and $R Q_{\text {output }}$ are assessed and compared to the legally required RQ. TBS technologies offer the possibility to generate a significantly higher-quality secondary product such as food packaging recyclate. Hence, an additional RQ is calculated exclusively for the food fractions available through TBS according to the input-based approach $\left(R Q_{\text {highquality }}\right)$.

\section{Results}

In the first step, the results show the system flow diagrams of all scenarios, the basis of the modelling, and following the quantitative results of the carbon footprint calculation. With a view to circulation, the results as well as the recycling rates resulting from the assessment are illustrated and analysed in more detail.

\section{Model of Conventional Sorting and Recycling System}

\section{Conventional Model}

The conventional system is divided into sorting and three following recycling opportunities. The aim was to create a realistic representation of the conventional system for LWP within Germany. Figure 2 shows an average technical sorting process for LWP.

Starting with successive classification and separation steps, packaging is sorted and then separated using sensorbased systems that use the physical material properties as a characteristic factor. (Christiani 2017; Dehoust and Christiani 2012; Institut cyclos-HTP GmbH 2019; Kranert and Cord-Landwehr 2010; Martens and Goldmann 2016).

Figure 3 gives an overview of the three recycling paths that follow the sorting process. After a final manual product monitoring, the sorted fractions are transferred to the appropriate recycling paths. Most plastic fractions are mechanically recycled into regranulate, and a small portion becomes RDF. After an additional sorting process, the plastics are washed, impurities are removed using a density separation and finally processed into regranulate in an extruder. In addition, the treatment of wastewater from the washing processes is included in the analysis (Deregowski 2020). Excluded from this process are mixed plastics (MP), which enter the recycling process for refuse-derived fuel together with the residues. These are 
Fig. 2 System flow chart of the conventional sorting of LWP (NIR, near-infrared spectroscopy; LC, liquid carton; MPO, mixed polyolefin; MP, mixed plastics packaging $(\mathrm{P}) /$ non-packaging (NP); PCC, paper, carton, cardboard; ACP, aluminium-containing packaging) own illustration based on Christiani 2017; Dehoust and Christiani 2012; Institut cyclosHTP GmbH 2019; Kranert and Cord-Landwehr 2010; Martens and Goldmann 2016

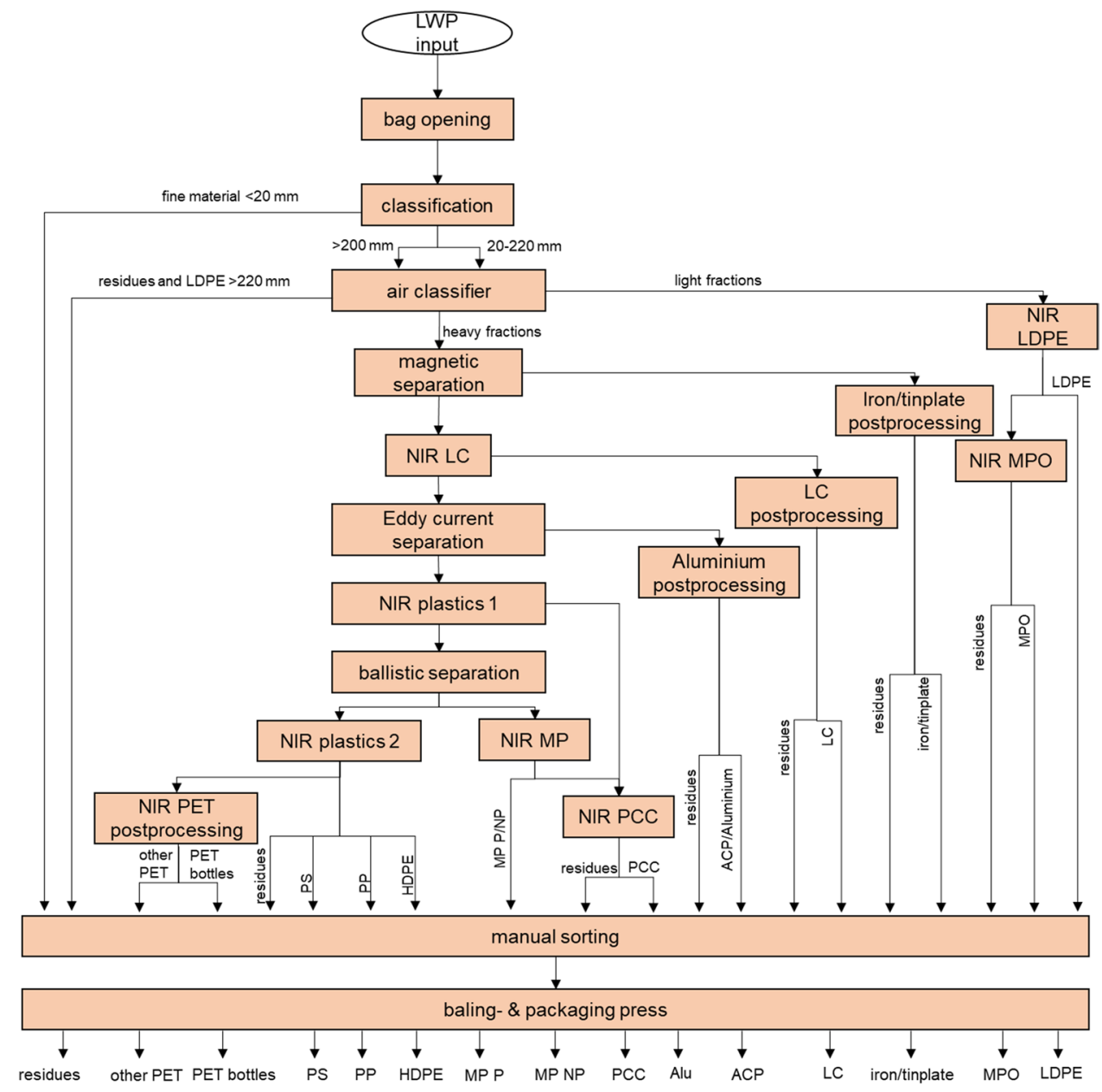

separated from impurities in the material flow over several sorting steps (Deregowski 2020). In addition, the processing to secondary pulp for the fractions paper, carton, cardboard (PCC) and liquid carton (LC) is considered. For this purpose, the pulp is shredded, softened in a stock solution and then recycled back to secondary pulp (Gromke and Detzel 2006).

\section{Scenario "TBS Light"}

In this scenario the conventional system is adapted for the application of the "TBS light" technology illustrated in Fig. 4. Only the differences to the conventional model are presented. The previous sorting processes remain completely identical and are supplemented by "TBS light" sorting units for the fractions HDPE, PP and PET bottles. Due to the improved sorting, manual re-sorting can be skipped (Dedler 2020). Based on (Woidasky et al. 2020b), a percentage distribution into food and non-food fractions is included.

\section{Scenario "TBS Complete"}

The second improvement scenario is the application of "TBS complete" whereby conventional sorting steps and technologies are replaced by the TBS sorting unit. Figure 5 illustrates the sorting process. The previous sorting remains in place up to and including the eddy current separation and can then be replaced by TBS units. Previously separated fractions (LDPE, MPO, iron/tinplate, LC, aluminium-containing packaging (ACP), aluminium) are therefore not affected by TBS and are manually re-sorted according to the conventional procedure. Separated residues are directed into TBS sorting units. Materials that have been previously unrecognisable or difficult to classify are considered to have potential for TBS; these mainly include the fractions residues and MP. After sorting, depending on the sub-scenario, different quantities of MP and residues are sent for mechanical recycling. An improvement due to significantly improved sorting is reflected in reduced waste quantities in the recycling steps. 
Fig. 3 System flow chart of the recycling paths (NIR, nearinfrared spectroscopy; MP, mixed plastics; PCC, paper, carton, cardboard; LC, liquid carton; RDF, refuse-derived fuel) own illustration based on Deregowski 2020; Gromke and Detzel 2006

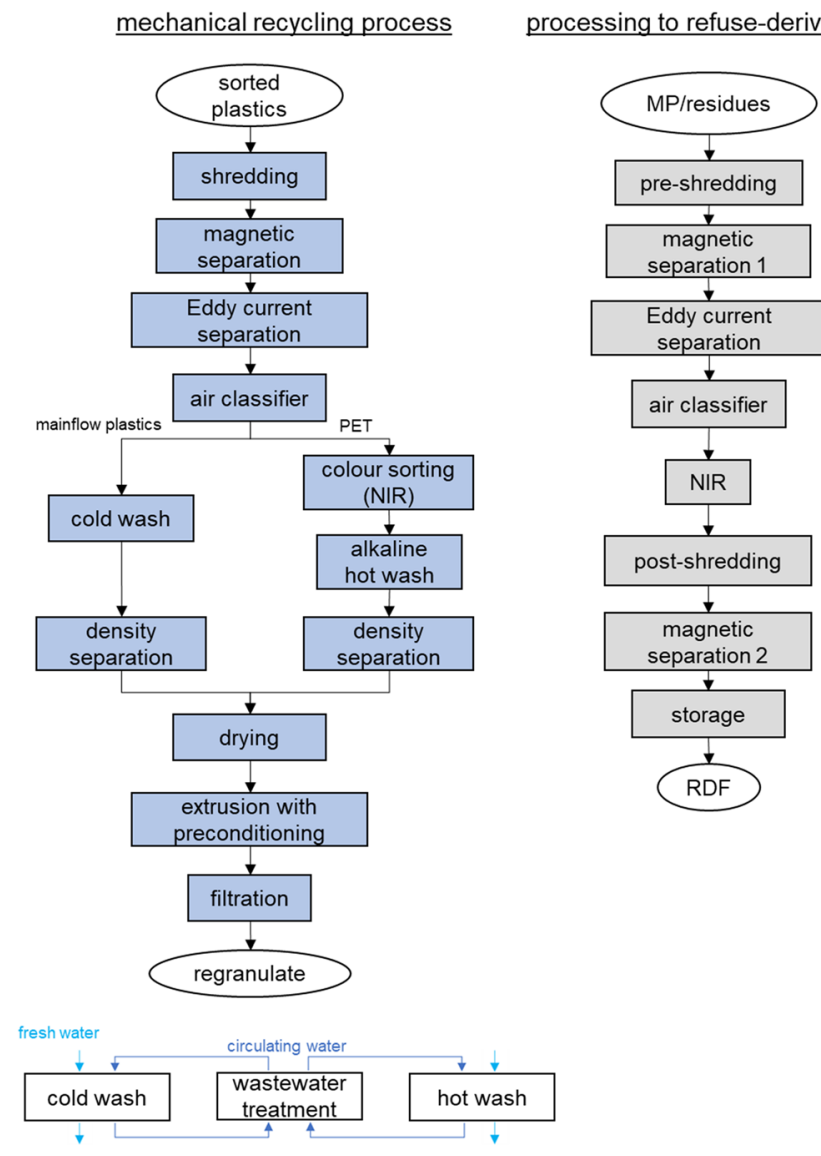

processing to secondary pulp

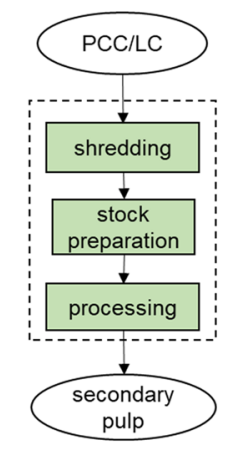

Fig. 4 System flow chart of the adaption of the conventional model to "TBS light" (red frame) (NIR, near-infrared spectroscopy; LC, liquid carton; MPO, mixed polyolefin; MP, mixed plastics packaging $(\mathrm{P}) /$ non-packaging (NP); PCC, paper, carton, cardboard; ACP, aluminium-containing packaging)

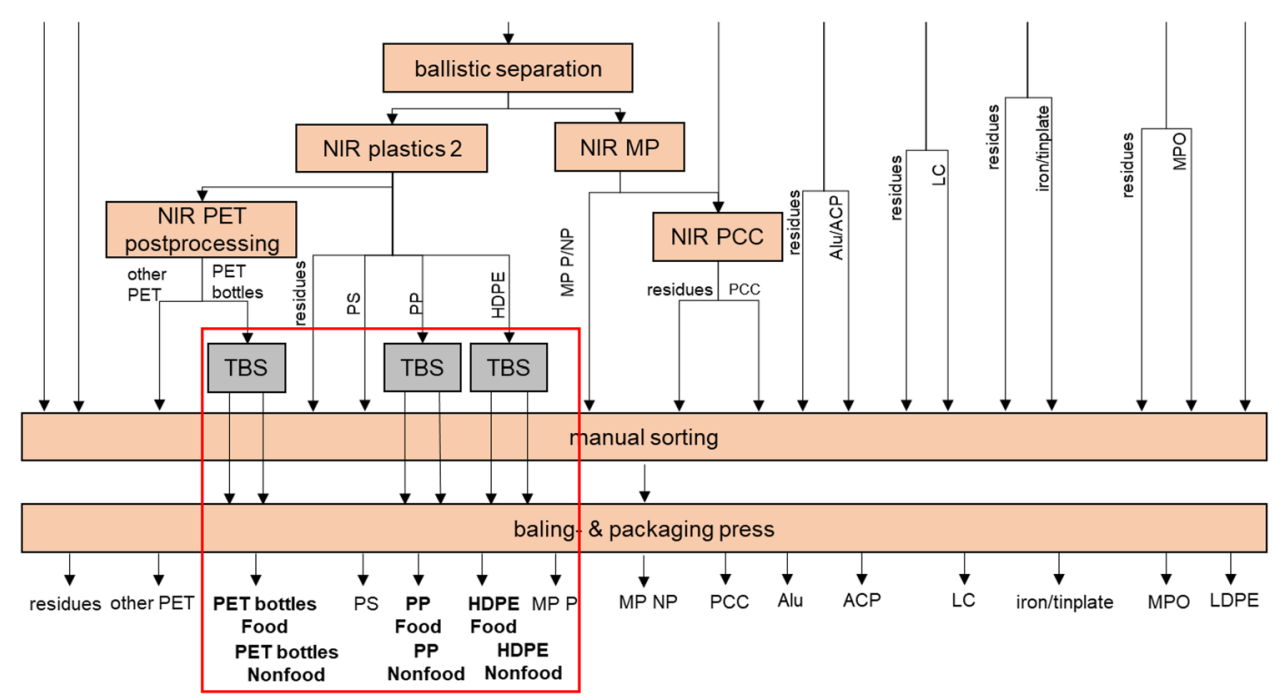

\section{Carbon Footprint}

Figure 6 gives an overview of the total result of all scenarios showing climate impacts and credits of LWP sorting and recycling. Per Mg of LWP the carbon footprint of conventional sorting processes has less climate impacts $(21.6 \mathrm{~kg}$ $\mathrm{CO}_{2}$-eq) compared to recycling (113.1 $\mathrm{kg} \mathrm{CO}_{2}$-eq). The main contribution to $\mathrm{CO}_{2}$-emissions originates from thermal energy needed in the extrusion process $\left(40.3 \mathrm{~kg} \mathrm{CO}_{2}\right.$-eq). This environmental burden is counterbalanced by credits $\left(700.1 \mathrm{~kg} \mathrm{CO}_{2}\right.$-eq) for the regranulates, which replace primary production products. Hence, the system yields net benefits of $565.4 \mathrm{~kg} \mathrm{CO}_{2}$-eq. 
Fig. 5 System flow chart of the sorting process with "TBS complete" (NIR, near-infrared spectroscopy; LC, liquid carton; MPO, mixed polyolefin; MP, mixed plastics packaging $(\mathrm{P}) /$ non-packaging (NP); PCC, paper, carton, cardboard; ACP, aluminium-containing packaging)

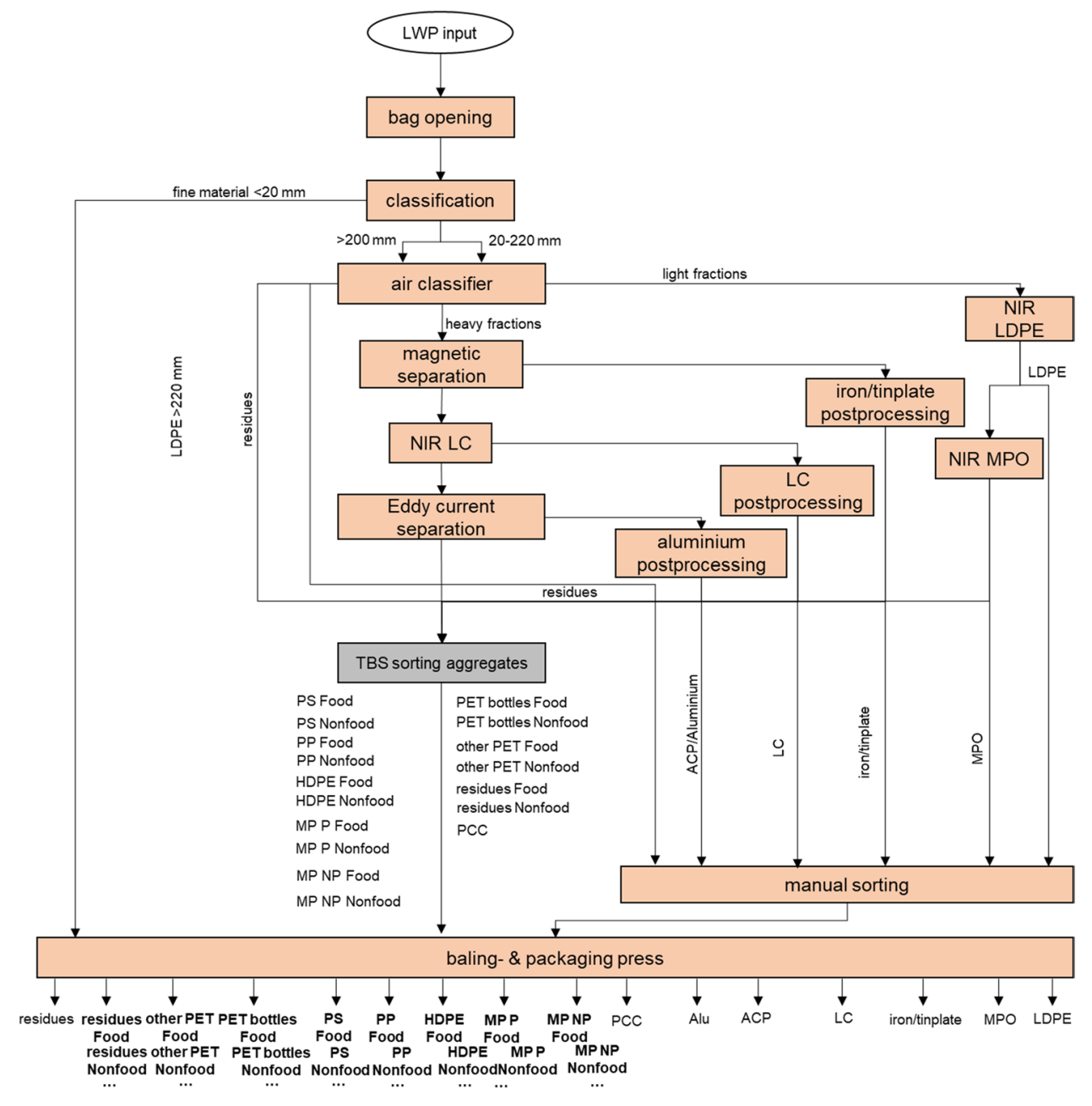

Fig. 6 Climate impacts and credits of LWP sorting and recycling (conventional, TBS light, and TBS complete) 
Fig. 7 Carbon footprint and recycling quotas of different LWP sorting and recycling scenarios

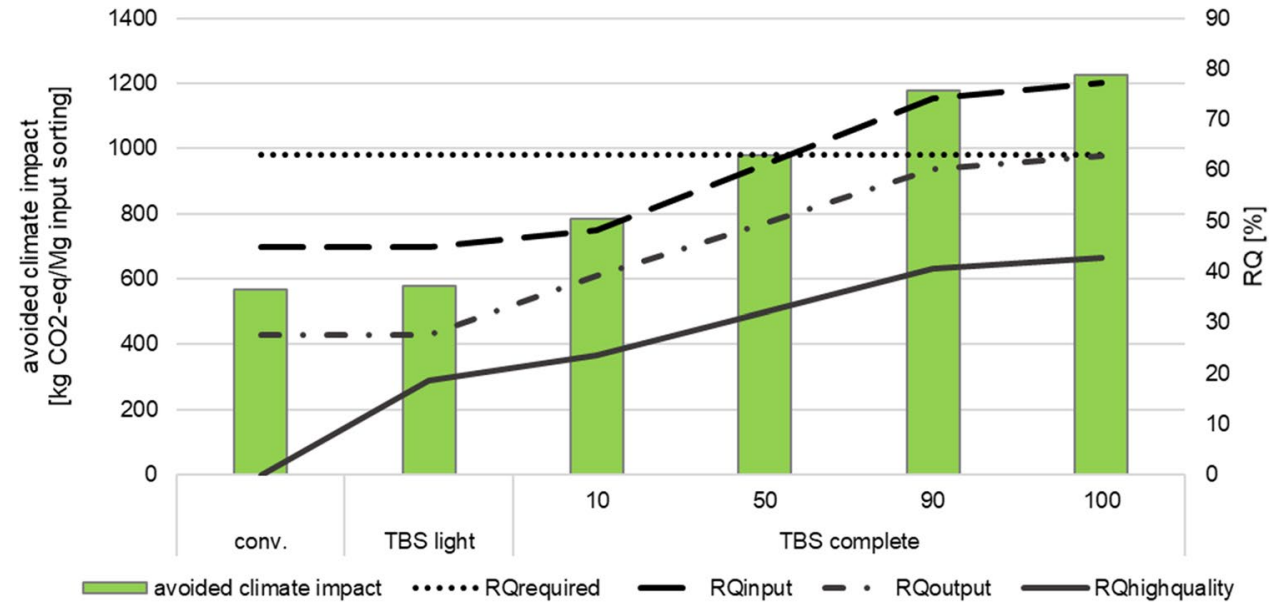

For the "TBS light" scenario, no significant changes in climate impacts of sorting and recycling occur compared to the conventional system. The additional impact of the TBS sorting units is compensated almost equally by the avoided climate impact of the saved process of manual sorting. The net benefit of the scenario is slightly higher $(578.2 \mathrm{~kg}$ $\mathrm{CO}_{2}$-eq) though due to higher credits for the TBS fractions (712.8 $\mathrm{kg} \mathrm{CO}_{2}$-eq).

Compared to the conventional and the "TBS light" scenario, the scenarios of "TBS complete" reveal an increase of sorting related climate impacts of roughly $20 \%$. Depending on the increase rate of mechanical recycling, the climate impacts of recycling increase by $14 \%$ in the $10 \%$-increase setting up to $46 \%$ in the $100 \%$-increase setting. The increase in sorting and recycling impacts is overcompensated by the carbon credits for the additional secondary material. The net benefits of "TBS complete" range from $783.9 \mathrm{~kg} \mathrm{CO}_{2}$-eq for $10 \%$-increase up to $1227.1 \mathrm{~kg} \mathrm{CO}_{2}$-eq for $100 \%$-increase.

In summary, an increase in avoided climate impacts can be observed across the sub-scenarios. The more plastic is recycled, the higher the associated savings. The significantly higher credits of the MP and residual fractions that can be recycled through "TBS complete" contribute in particular to the saved climate impacts.

\section{Circularity}

Figure 7 relates the final results of the carbon footprint, the avoided climate impact, to the calculated recycling quotas for all scenarios. The calculation basis of the recycling quota (RQ) can be found in Chapter 2.2.

The result of the input-based approach $\left(\mathrm{RQ}_{\text {input }}\right)$ of $44.97 \%$ for the conventional system for plastics packaging recycling clearly shows the need for action, as the quote of $58.5 \%\left(\mathrm{RQ}_{\text {required }}\right)$ currently legally required in Germany is not achieved. This result is consistent with recycling quotas for LWP in Germany published recently (Schüler 2020), which amount to $46.4 \%$ only. The same applies to "TBS light", as this scenario implies that the recycling quantity of plastics will not increase substantially. The use of "TBS complete" has a significant effect on the RQ. The scenarios 90 and 100 show the potential of the technology with RQs of $74.10 \%$ and $77.34 \%$, respectively. In order to meet the 2022 quota, at least $56 \%$ of the mixed plastics and residues need to be mechanically recycled.

Compared to the input-based approach, the calculation using the output flows $\left(\mathrm{RQ}_{\text {output }}\right)$ shows how much plastic is actually returned to the life cycle. $\mathrm{RQ}_{\text {output }}$ of the conventional model and of "TBS light" is then reduced to $27.53 \%$. Even with the current sub-scenario 50, the required quota cannot be achieved. The current quota of $58.5 \%$ can only be achieved with a mechanical recycling of $90 \%$ of the MP and residues. Hence, the RQ of $63 \%$, required in Germany from 2022 on, cannot be achieved even with "TBS complete" yet. Consequently, the results show an urgent need for action and the importance of further development.

$\mathrm{RQ}_{\text {highquality }}$ reflects TBS ability to generate higher quality secondary products such as food packaging recyclate. Unlike current NIR sorting processes, TBS offers the potential to identify food-grade packaging items in the sorting process, regardless of the material they are consisting of. Consequently, food grade polymers can be recovered by TBS, which along with adequate cleaning steps in mechanical recycling can be applied in these types of packaging again (Geueke et al. 2018). The implementation of "TBS light" enables $18.66 \%$ of the plastic waste to be processed into high-quality secondary product. With "TBS complete", a further increase is possible from $23.53 \%$ (10), $32.06 \%$ (50), $40.59 \%$ (90) up to $42.72 \%$ (100). Consequently, TBS reduces the climate impact and returns a significant higher-quality secondary product to the circular economy. 


\section{Discussion and Conclusion}

The interplay and integration of LCA and circular economy is a recent research issue in industrial ecology research (Haupt and Zschokke 2017; Dieterle et al. 2018). The transformation to a circular economy requires new business models and newly emerging technologies and needs to understand associated environmental impacts, which is a challenging task for LCA (Hetherington et al. 2014; Arvidsson et al. 2018). This paper offers a pragmatic contribution to the discussion on prospective LCA of emerging technologies by combining data from established recycling and sorting systems with prospective data from pilot TBS plants.

The material and energy flow models presented within this paper enable a detailed process-specific analysis of recycling and sorting processes of LWP wastes with regard to climate impacts and recycling quota in Germany. The conventional recycling and sorting model is based on primary data from recycling and sorting plant operators, on expertise from practitioners in the field, and on measurements of actual LWP waste fractions. Thus, relevant stakeholders and experts were included which is an important step for the evaluation and assessment of uncertainties in the evaluation of future innovative technologies (Van der Giesen et al. 2020). Overall, the use of practice data and existing LCI datasets is assessed with low uncertainty and high accuracy compared to assumptions and calculations (Parvatker and Eckelman 2019). Nevertheless, assumptions have to be taken at various points in the model to fill data gaps and to approximate orders of magnitude and trends. As a consequence, for the modelling of sorting and recycling paths, an existing plant is used as a reference in each case, and linearity is assumed for the calculation of inputs. Our model provides a factual baseline model and scenario for the current LWP management situation in Germany and thus serves as a reference tool for assessment of sorting and recycling innovations. Triggered by increasing legal pressure on LWP material recycling, such innovations are required and expected in the near future. The parameterised model enables prospective assessments for technological changes especially in the sorting phase. In the case presented, it is used to elaborate projections of the consequences of tracer-basedsorting (TBS) technology on material recycling. The current TBS technology readiness level is at pilot stage and has not yet been fully introduced to the market and implemented in a plant. Hence, pilot plant results along with assumptions validated by experts have been used to build various scenarios of TBS implementation. These scenarios are used to analyze potential environmental impacts of avoiding incineration/use as a RDF due to improved sorting. As shown in the literature (e.g. Van der Giesen et al. 2020), the results of ecological assessments of future technologies are often not exact but rather indicative. They provide an overview and basis for discussion and R\&D. The results of this study have been discussed in the project consortium and were used to improve the carbon footprint of TBS.

TBS can be regarded either as an extension of current sorting technology (Martens and Goldmann 2016) in the scenario "TBS light" or as an alternative technology if "TBS complete" is implemented. Given the current constraints and path dependencies in central Europe (due to the existing sorting and recycling infrastructure), "TBS light" might have a higher probability for implementation under the current conditions. Nonetheless, substantial effort is required to achieve circularity for lightweight packaging (Elnser et al. 2021). Technology development results of TBS show that unlike current techniques TBS enables high-quality recycling, i.e. leads to recyclates that can be used again in similar applications (packaging to packaging) (Geueke et al. 2018). This is a clear advantage over conventional technologies, which until now have sorted exclusively based on material properties only, with regranulates rarely meeting the requirements for high-quality use, e.g. in the food packaging industry. It has to be mentioned though that identification of food-grade material in recycling is a necessity, but also the sufficient condition of freedom from contaminants (e.g. stemming from unintended use of the packaging) has to be met (Geueke et al. 2018). Consequently, TBS sorting can be regarded as providing the necessary condition for circularity, although for a fully sufficient quality additional cleaning steps in mechanical recycling may become necessary.

To this end, our study quantifies additional efforts and climate impacts for TBS, in particular for more comprehensive TBS solutions ("TBS complete") in an early stage of development, to make sure an appropriate balance of efforts and benefits when modifying the waste management system (Huysman et al. 2017). These additional efforts are however justified by the even higher credits due to savings of primary material production. This is true for optimistic and pessimistic TBS scenarios alike. Based on the conventional sorting and recycling system, $565.44 \mathrm{~kg} \mathrm{CO}_{2}$-eq/Mg LWP sorted of environmental impact can already be saved due to the credits. Depending on the implementation scenario, these savings increase from $578 \mathrm{~kg} \mathrm{CO}_{2}$-eq/Mg LWO sorted to up to $1227 \mathrm{~kg} \mathrm{CO}_{2}$-eq/Mg LWP sorted using tracer-based-sorting. These results confirm findings from current LCA studies on plastics recycling in a circular economy, which show the environmental superiority of closed-loop or high-quality recycling in comparison to incineration, energy recovery or open-loop recycling (Schwarz et al. 2021).

The challenges and goals for improving plastic recyclability and especially to ensure recyclability of all plastic packaging by 2030 (European Commission 2018) can only be met if both packaging properties and sorting and recycling technologies are improved (Birnstengel et al. 2018; Schwarz 
et al. 2021). Material-independent identification and sorting approaches which work well under challenging waste management conditions are technological options to ensure circular economy for plastic packaging. Fluorescence-based TBS as described in this paper is one such technology. Assuming that it meets these challenges, it can be regarded as an innovative and future-oriented technology for sorting and high-quality recycling of plastics even in particularly difficult areas such as food packaging. As identified in this paper, it can contribute to a more resource-efficient plastic packaging circular economy.

The research presented was conducted in the research project "MaReK - Marker based sorting and recycling system for plastic packaging", made possible by a grant of the German Federal Ministry for Education and Research (BMBF) as a part of the framework program "Research for Sustainable Development" (FONA3) on the topic "Plastics in the environment" with grants no. 033R195A-E under supervision of the project executing organization Jülich (PTJ).

Acknowledgements The authors are thankful for the support of KIT, Der Grüne Punkt—DSD GmbH, Werner \& Mertz GmbH and Umwelttechnik BW GmbH. The sole responsibility for this text is with the authors. The authors would like to thank the project partners for the valuable input and fruitful discussions.

Author contribution Conceptualization, A.K., J.G., T.V., J. W., C. L.; methodology, A. K, T.V.; data acquisition and assessment, A.K., C.D.; writing - original draft preparation, A. K., J. G.; writing-review and editing, A.K., J.G., T.V., J. W., C. L.; visualization, A. K.; project administration, J.W. and C.L. All authors have read and agreed to the published version of the manuscript.

Funding Open Access funding enabled and organized by Projekt DEAL. We thankfully acknowledge funding by the German Federal Ministry for Education and Research (BMBF) as a part of the framework program "Research for Sustainable Development" (FONA3) on the topic "Plastics in the environment" with grants no. 033R195A-E under supervision of the project executing organization Jülich (PTJ).

Data availability The data presented in this study are available on request from the corresponding author. The data are not publicly available due to privacy reasons.

\section{Declarations}

Conflict of interest The authors declare no competing interests.

Open Access This article is licensed under a Creative Commons Attribution 4.0 International License, which permits use, sharing, adaptation, distribution and reproduction in any medium or format, as long as you give appropriate credit to the original author(s) and the source, provide a link to the Creative Commons licence, and indicate if changes were made. The images or other third party material in this article are included in the article's Creative Commons licence, unless indicated otherwise in a credit line to the material. If material is not included in the article's Creative Commons licence and your intended use is not permitted by statutory regulation or exceeds the permitted use, you will need to obtain permission directly from the copyright holder. To view a copy of this licence, visit http://creativecommons.org/licenses/by/4.0/.

\section{References}

Arenas-Vivo A, Beltrán FR, Alcázar V, de la Orden MU, Urreaga J (2017) Fluorescence labeling of high density polyethylene for identification and separation of selected containers in plastics waste streams. Comparison of thermal and photochemical stability of different fluorescent tracers. Materials Today Communications 12:125-132. https://doi.org/10.1016/j.mtcomm.2017.07.008

Arvidsson R, Tillmann A, Sandén B, Janssen M, Nordelöf A, Kushnir D, Molander S (2018) Environmental assessment of emerging technologies: recommendations for prospective LCA. J Ind Ecol 22:1286-1294. https://doi.org/10.1111/jiec.12690

Birnstengel B; Eckhardt M, Häusler A, Hoffmeister J, Labinsky A, Lambert J, Lühr O, Schütz N, Simpson R (2018) Statusbericht der deutschen Kreislaufwirtschaft 2018. Einblicke und Aussichten. [Status Report of the German Circular Economy 2018. Insights and Perspectives.]. Düsseldorf, https://www.bvse.de/images/pdf/ Nachrichten_2018/Statusbericht_2018_Ansicht_und_Druck.pdf. Assessed 15 October 2020

Brunner S, Fomin P, Kargel C (2015) Automated sorting of polymer flakes fluorescence labeling and development of a measurement system prototype. Waste management New York 38:49-60. https://doi.org/10.1016/j.wasman.2014.12.006

Bünemann A, Rachut G, Christiani J, Langen M, Wolters J (2011) Planspiel zur Fortentwicklung der Verpackungsverordnung Teilvorhaben 1: Bestimmung der Idealzusammensetzung der Wertstofftonne. [Planning simulation for the further development of the packaging regulation sub-project 1 : determining the ideal composition of the recyclables bin.]. Federal Environment Agency. Dessau-Roßlau, https://www.umweltbundesamt.de/sites/default/ files/medien/461/publikationen/4074.pdf. Assessed 22 October 2020

Christiani J, Griepentrog U, Weber H, Giegrich J, Detzel A, Breuer L (2001) Grundlagen für eine ökologisch und ökonomisch sinnvolle Verwertung von Verkaufsverpackungen. [Fundamentals for an ecologically and economically beneficial recycling of sales packaging] (Forschungsbericht 298 33719). Federal Environment Agency. Berlin, https://www.umweltbundesamt.de/sites/default/ files/medien/publikation/long/2258.pdf. Assessed 10 November 2020

Christiani J (2017) Recycling und Recyclingfähigkeit bei Verpackungen - Das neue VerpackG in der Praxis. Stand der Technik und Herausforderungen für einzelne Verpackungsmaterialen [Recycling and recyclability in packaging - The new Packaging Act in practice. State of the art and challenges for individual packaging materials]. HTP Ingenieurgesellschaft. Berlin. https://www.bvse. de/images/pdf/Themen__Ereignisse/2017/1-Christiani_Stand_ der_Technik_.pdf. Assessed 10 October 2020

Coelho TM, Castro R, Gobbo JA (2011) PET containers in Brazil: Opportunities and challenges of a logistics model for post-consumer waste recycling. Resour Conserv Recycl 55(3):291-299. https://doi.org/10.1016/j.resconrec.2010.10.010

Corona B, Shen L, Reike D, Rosales Carreón J, Worrell E (2019) Towards sustainable development through the circular economyA review and critical assessment on current circularity metrics. Resources, Conservation and Recycling 151, S. 104498. https:// doi.org/10.1016/j.resconrec.2019.104498

Dedler S (2020) Business Case Tracer-Based Sorting: Wirtschaftlichkeitsbetrachtung einer Technologie für das Kunststoffrecycling der Zukunft. [Business case tracer-based sorting: economic 
analysis of a technology for plastics recycling of the future]. Bachelor thesis. Pforzheim University of Applied Sciences. Pforzheim

Dehoust G, Christiani J (2012) Analyse und Fortentwicklung der Verwertungsquoten für Wertstoffe. Sammel- und Verwertungsquoten für Verpackungen und stoffgleiche Nichtverpackungen als Lenkungsinstrument zur Ressourcenschonung. [Analysis and further development of recycling rates for recyclable materials. Collection and recovery rates for packaging and non-packaging of the same material as a steering instrument for resource conservation.]. Federal Environment Agency. Dessau-Roßlau. https://www.umwel tbundesamt.de/sites/default/files/medien/461/publikationen/4342. pdf. Assessed 10 October 2020

Deregowski C (2020) Potenzielle Umweltbelastungen der Entsorgung von Standbodenbeutelverbundverpackungen. [Potential environmental impacts of the disposal of composite stand-up pouches]. Version of 22.07.2020. Master thesis. Pforzheim University of Applied Sciences, Pforzheim.

Destatis (2020) Umwelt Abfallbilanz 2018. (Abfallaufkommen/verbleib, Abfallintensität, Abfallaufkommen nach Wirtschaftszweigen). [Environment Waste Balance 2018. (Waste generation/ retention, waste intensity, waste generation by economic sector).]. Federal Statistical Office. Wiesbaden. https://www.destatis.de/DE/ Themen/Gesellschaft-Umwelt/Umwelt/Abfallwirtschaft/Publi kationen/Downloads-Abfallwirtschaft/abfallbilanz-pdf-53210 01.pdf;jsessionid=A67EB8A58A73F75E4CD97FA2516FD186. internet8731? blob=publicationFile. Assessed 10 October 2020

Detzel A, Böß A (2006) Ökobilanzieller Vergleich von Getränkekartons und PET-Einwegflaschen. [Life cycle assessment comparison of beverage cartons and PET disposable bottles]. Heidelberg. https://getraenkekarton.de/media/file/9.OEkobilanz_GKvsPET_ 22_8_06.pdf. Assessed 15 October 2020

Detzel A, Kauertz B, Grahl B, Heinisch J (2016) Prüfung und Aktualisierung der Ökobilanzen für Getränkeverpackungen. [Review and update of life cycle assessments for beverage packaging]. Federal Environment Agency. Dessau-Roßlau. https://www.umweltbund esamt.de/sites/default/files/medien/378/publikationen/texte_19_ 2016_pruefung_und_aktualisierung_der_oekobilanzen_fuer_ gertaenkeverpackungen_0.pdf. Assessed 15 October 2020

Dieterle M, Schäfer P, Viere T (2018) Life cycle gaps: interpreting LCA results with a circular economy mindset. Procedia CIRP 69:764-768. https://doi.org/10.1016/j.procir.2017.11.058

DIN EN ISO 14040:2009-11, Environmental management_- life cycle assessment_- principles and framework (ISO_14040:2006); German and English version EN_ISO_14040:2006

DIN EN ISO 14067:2019-02, Greenhouse gases_- carbon footprint of products_- requirements and guidelines for quantification (ISO_14067:2018); German and English version EN_ISO_14067:2018

DSD - Duales System Deutschland GmbH (2020): Downloads - Spezifikationen. [Specifications]. https://www.gruener-punkt.de/de/ downloads.html. Accessed 2 June 2020

ecoinvent (2020) ecoinvent 3.6. https://www.ecoinvent.org/database/ ecoinvent-36/ecoinvent-36.html. Assessed 24 May 2020

Elnser, P, Müller-Kirschbaum, T, Schweitzer K, Wolf R, Seiler E, Désilets P, Detsch R, Dornack C, Ferber J, Fleck C, Fröhling M, Hagspiel K, Hahn R, Haupts C, Hoffmann C, Krüger P, Lange M, Leopold T, Löscher M, Niedersüß P, Ohlendorf T, Pattberg J, Renner M, Schlarb A K, Schmidt M, Siebert H, Siggelkow B A, Stadelmann S, Thielen J, Wilts H, Beermann M, Dieterle M, Ecke N, Klose S, Kobus J, Krause L, Maletz R, Marm A, Kadner S (2021) Kunststoffverpackungen im geschlossenen Kreislauf. [Closed-loop plastic packaging]. Circular Economy Initiative Deutschland. Berlin. https://static1.squarespace.com/static/5b520 37e4611a0606973bc79/t/604b79dc3de9065613846049/16155
59148759/VP_Gesamtbericht+DE_Web_final.pdf. Assessed 19 March 2021

European Commission (2015) Closing the loop - An EU action plan for the Circular Economy. Brussel. https://eur-lex.europa.eu/resource. html?uri=cellar:8a8ef5e8-99a0-11e5-b3b7-01aa75ed71a1.0012. 02/DOC_1\&format=PDF

European Commission (2018) A European strategy for plastics in a circular economy. Brussel. https://eur-lex.europa.eu/legal-content/ EN/TXT/?qid=1516265440535\&uri=COM:2018:28:FIN

European Commission (2020) New circular economy action plan. For a cleaner and more competitive Europe. Brussel. https://eur-lex. europa.eu/legal-content/EN/TXT/?qid=1583933814386\&uri= COM:2020:98:FIN

European Commission; Joint Research Centre; Institute for Environment and Sustainability (2012) Characterisation factors of the ILCD recommended life cycle impact assessment methods. Database and Supporting Information. First edition. Publications Office of the European Union. Luxemburg (EUR 25167)

European Parliament (2018) Richtlinie (EU) 2018/851 des europäischen Parlaments und des Rates zur Änderung der Richtlinie 2008/98/EG über Abfälle. [Directive (EU) 2018/851 of the European Parliament and of the Council of 30 May 2018 amending Directive 2008/98/EC on waste]. European Union. https://eur-lex. europa.eu/legal-content/DE/TXT/PDF/?uri=CELEX:32018L0851 $\&$ from $=\mathrm{DE}$

European Union (2019) COMMISSION IMPLEMENTING DECISION (EU) 2019/1004 of 7 June 2019 laying down rules for the calculation, verification and reporting of data on waste in accordance with Directive 2008/98/EC of the European Parliament and of the Council and repealing Commission Implementing Decision C(2012) 2384. Assessed 28 January 2021

Finnveden G (1999) Methodological aspects of life cycle assessment of integrated solid waste management systems. Resour Conserv Recycl 26(3-4):173-187. https://doi.org/10.1016/S0921-3449(99) 00005-1

Gasde J, Woidasky J, Moesslein J, Lang-Koetz C (2021) Plastics recycling with tracer-based-sorting: challenges of a potential radical technology. Sustainability 13(1):258. https://doi.org/10.3390/ su13010258

German Packaging Law (2017) Gesetz über das Inverkehrbringen, die Rücknahme und diehochwertige Verwertung von Verpackungen. VerpackG. [Act on the placing on the market, returnand high-quality recovery of packaging.]. Fundstelle: BGBl. https://www.geset ze-iminternet.de/verpackg/VerpackG.pdf. Accessed 30 May 2020

Geueke B, Groh K, Muncke J (2018) Food packaging in the circular economy: Overview of chemical safety aspects for commonly used materials. J Clean Prod 193:491-505. https://doi.org/10. 1016/j.jclepro.2018.05.005

Grigore M (2017) Methods of recycling, properties and applications of recycled thermoplastic polymers. Recycling 2(4):24. https://doi. org/10.3390/recycling2040024

Gromke U, Detzel A (2006) Ökologischer Vergleich von Büropapieren in Abhängigkeit vom Faserrohstoff. [Ecological comparison of office papers in relation to the fibre raw material], IFEU Heidelberg

Haupt M, Zschokke M (2017) How can LCA support the circular economy? The International Journal of Life Cycle Assessment 22:832-837. https://doi.org/10.1007/s11367-017-1267-1

Hauschild M, Huijbregts MAJ (2015) Life cycle impact assessment. Springer, Netherlands, Dordrecht

Heijungs R, Guinée JB (2007) Allocation and "what-if" scenarios in life cycle assessment of waste management systems. Waste management New York 27(8):997-1005. https://doi.org/10.1016/j. wasman.2007.02.013

Hellerich W, Harsch G, Haenle S (2010) Werkstoff-Führer Kunststoffe. Eigenschaften, Prüfungen, Kennwerte. [Materials Guide Plastics. 
Properties, tests, characteristic values]10. Aufl. s.l. Carl Hanser Fachbuchverlag. Munich

Hetherington AC, Borrion AL, Griffiths OG, McManus MC (2014) Use of LCA as a development tool within early research. Int J Life Cycle Assess 19:130-143. https://doi.org/10.1007/ s11367-013-0627-8

Huysman S, Schaepmeester J, Ragaert K, Dewulf J, Meester S (2017) Performance indicators for a circular economy. A case study on post-industrial plastic waste. Resour Conserv Recycl 120:46-54. https://doi.org/10.1016/j.resconrec.2017.01.013

ifu Institut für Umweltinformatik Hamburg GmbH (2017) User Manual Umberto LCA+. Hamburg. https://www.ifu.com/fileadmin/user_ upload/umberto/Support/Support-Dokumente/Umberto_LCAPI us_User_Manual_WEB.pdf. Accessed 17 June 2020

ifu Institut für Umweltinformatik Hamburg GmbH (2020) Umberto LCA+ 10.0.3. https://www.ifu.com/en/umberto/

Ignatyev IA, Thielemans W, Vander Beke B (2014) Recycling of polymers: a review. Chemsuschem 7(6):1579-1593. https://doi.org/10. 1002/cssc. 201300898

Institut cyclos-HTP GmbH (2019) Prüfung und Testierung der Recyclingfähigkeit. Anforderungs- und Bewertungskatalog des Institutes cyclos-HTP zur EU-weitern Zertifizierung. [Examination and testing of recyclability. Requirements and evaluation catalogue of the cyclos-HTP Institute for EU-wide certification]. Aachen

IPCC - Intergovernmental Panel on Climate Change (2015) Climate change 2014. Synthesis report. With collaboration of R. K. Pachauri und Leo Mayer. Intergovernmental Panel on Climate Change. Geneva, Switzerland: Intergovernmental Panel on Climate Change

ITAD (2015) Analyse/Beschreibung der derzeitigen Situation der stofflichen und energetischen Verwertung von Kunststoffabfällen in Deutschland. [Analysis/description of the current situation of material and energy recovery of plastic waste in Germany]. Consultic Marketing \& Industrieberatung $\mathrm{GmbH}$. Alzenau

Jambeck J R, Geyer R, Wilcox C, Siegler T R, Perryman M, Andrady A, Narayan R, Law K L (2015) Plastic waste inputs from land into the ocean. Science (New York, N.Y.) (347 (6223)), p. 768-771. https://doi.org/10.1126/science.1260352

Kälber J (2019) Ökologische Bewertung zweier Szenarien zur Kreislaufführung einer Kunststoffverpackung unter Verwendung der TBS-Technologie. [Ecological evaluation of two scenarios for the recycling of a plastic packaging using the TBS technology]. Master thesis. Pforzheim University of Applied Sciences, Pforzheim. Institute for Industrial Ecology

Kauertz B, Döhner A, Detzel A (2011) Ökobilanz von Getränkeverpackungen in Österreich Sachstand 2010. [Life cycle assessment of beverage packaging in Austria Status 2010]. Ifeu- Institut für Energie- und Umweltforschung. Heidelberg. https://www.ifeu.de/ oekobilanzen/pdf/Oekobilanz_\%20Getraenkeverpackungen_Oeste rreich\%202010_Langfassung.pdf. Assessed 10 July 2020

Klöpffer W, Grahl B (2009) Ökobilanz (LCA). Ein Leitfaden für Ausbildung und Beruf. [Life Cycle Assessment (LCA). A guide for education and business], WILEY-VCH Verlag GmbH \& Co. KGaA. Weinheim

Kranert M, Cord-Landwehr K (2010) Einführung in die Abfallwirtschaft. [Introduction to waste management] Vieweg+Teubner Verlag. Wiesbaden

Kreibe S, Pitschke T, Berkmüller R, Bokelmann M, Förster A (2017) Umweltbezogene Bilanzierung von ,intelligenten“ und ,aktiven“ Verpackungen hinsichtlich der Recyclingfähigkeit und Durchführung eines Dialogs mit Akteuren der Entsorgungs- und Herstellungsbranchen. [Environmental balancing of "intelligent" and "active" packaging with regard to recyclability and conducting a dialogue with stakeholders in the disposal and manufacturing industries]. Federal Environment Agency. Dessau-Roßlau. https:// www.umweltbundesamt.de/sites/default/files/medien/1410/publi kationen/2017-03-14_texte_22-2017_bilanzierung-verpackung. pdf. Assessed 20 July 2020

Kreislaufwirtschaftsgesetz (2012) Gesetz zur Förderung der Kreislaufwirtschaft und Sicherung der umweltverträglichen Bewirtschaftung von Abfällen. [Act to promote the circular economy and ensure the environmentally compatible management of waste.]. KrWG. Fundstelle: BGBI. https://www.gesetze-im-inter net.de/krwg/. Assessed 07 August 2020

Kusch A (2020) Ökobilanzielle Bewertung der Sortierung und Verwertung von Leichtverpackungen aus Kunststoff mit Betrachtung der Optionen durch TBS - Forschungsprojekt „MaReK“. [Ecological assessment of sorting and recycling of lightweight plastic packaging with consideration of options using TBS - research project "MaReK".]. Master thesis. Pforzheim University of Applied Sciences, Pforzheim. Institute for Industrial Ecology

Maris E, Aoussat A, Naffrechoux E, Froelich D (2012) Polymer tracer detection systems with UV fluorescence spectrometry to improve product recyclability. Miner Eng 29:77-88. https://doi.org/10. 1016/j.mineng.2011.09.016

Martens H, Goldmann D (2016) Recyclingtechnik. Fachbuch für Lehre und Praxis. 2. Auflage. [Recycling Technology. Textbook for teaching and practice ]. Springer Vieweg. Wiesbaden

MEILO - MEILO Gesellschaft zur Rückgewinnung sortierter Werkstoffe mbH \& Co. KG (2020) Hochwertiger Output. [High quality output]. https://www.meilogernsheim.de/leistungen/hochwertig er-output/. Accessed 15 June 2020

Moser H, Fabian M, Jung M, Heutling S, Körber G, Oehme I (2016) Steigerung des Kunststoffrecyclings und des Rezyklateinsatzes. [Increasing plastics recycling and the use of recycled materials.] Federal Environment Agency. Dessau-Roßlau. https://www. umweltbundesamt.de/sites/default/files/medien/377/publikatio nen/170601_uba_pos_kunststoffrecycling_dt_bf.pdf. Assessed 15 July 2020

Parvatker AG, Eckelman MJ (2019) Comparative evaluation of chemical life cycle inventory generation methods and implications for life cycle assessment results. ACS Sustain Chem Eng 7:350-367. https://doi.org/10.1021/acssuschemeng.8b03656

PlasticsEurope AISBL (2019) The circular econonomy for plastics. A European Overview. Brüssel. https://www.plasticseurope.org/ de/resources/publications/1899-circular-economy-plastics-europ ean-overview. Assessed 06 August 2020

PlasticsEurope AISBL; EPRO (2018) Plastics - the Facts 2018 an analysis of European plastics production, demand and waste data. https://www.plasticseurope.org/application/files/6315/4510/9658/ Plastics_the facts_2018_AF_web.pdf. Assessed 07 August 2020

Roosen M, Mys N, Kusenberg M, Billen P, Dumoulin A, Dewulf J, Van Gem K, Ragaert K, De Meester S (2020) detailed analysis of the composition of selected plastic packaging waste products and its implications for mechanical and thermochemical recycling. Environ Sci Technol 54(20):13282-13293. https://doi.org/10. 1021/acs.est.0c03371

Ragaert K, Delva L, van Geem K (2017) Mechanical and chemical recycling of solid plastic waste. Waste management New York 69:24-58. https://doi.org/10.1016/j.wasman.2017.07.044

Schonert M, Motz G, Meckel H, Detzel A, Giegrich J, Ostermayer A, Schorb A, Schmitz S (2002) Ökobilanz für Getränkeverpackungen II / Phase 2. [Life cycle assessment for beverage packaging II / phase 2]. Federal Environment Agency. Berlin. https://www. umweltbundesamt.de/sites/default/files/medien/publikation/long/ 2180.pdf. Assessed 12 May 2020

Schüler K (2020) Aufkommen und Verwertung von Verpackungsabfällen in Deutschland im Jahr 2018. Abschlussbericht. [Generation and recovery of packaging waste in Germany in 2018. 
Final report.]. Federal Environment Agency. Dessau-Roßlau (166/2020). https://www.umweltbundesamt.de/sites/default/ files/medien/479/publikationen/texte_166-2020_aufkommen_ und_verwertung_von_verpackungsabfaellen_in_deutschland_ im_jahr_2018.pdf. Assessed 02 November 2020

Schwarz AE, Ligthart TN, Bizarro DG, De Wild P, Vreugdenhil B, Harmelen V (2021) Plastic recycling in a circular economy; determining environmental performance through an LCA matrix model approach. Waste Manage 121:331-342. https://doi.org/10.1016/j. wasman.2020.12.020

Shen L, Worrell E (2014) Plastic Recycling // Handbook of recycling. State-of-the-art for practitioners, analysts, and scientists. Amsterdam, Boston, Heidelberg, London, New York, Oxford, Paris, San Diego, San Francisco, Sydney, Tokyo: Elsevier

Stahel WR (2016) The circular economy. Nature 531(7595):435-438. https://doi.org/10.1038/531435a

Suski P, Wiesen K (2016) Einsatz von Sekundärmaterial vs. recyclinggerechtes Design: Diskussion verschiedener End-of-Life-Allokationen unter Berücksichtigung der europäischen Abfallhierarchie. [Use of secondary materials vs. design for recycling: discussion of different end-of-life allocations taking into account the European waste hierarchy]. uwf UmweltWirtschaftsForum 24 (1), p. 7-13. https://doi.org/10.1007/s00550-016-0395-6

Urban A I, Halm G (2012) Herausforderungen an eine neue Kreislaufwirtschaft. [Challenges for a new circular economy]. Kassel University Press GmbH (Schriftenreihe des Fachgebietes Abfalltechnik. Unikat, Bd. 15). Kassel

Van der Giesen C, Cucurachi S, Guinée J, Kramer GJ, Tukker A (2020) A critical view on the current application of LCA for new technologies and recommendations for improved practice. J Clean Prod 259:120904. https://doi.org/10.1016/j.jclepro.2020.120904
Wernet G, Bauer C, Steubing B, Reinhard J, Moreno-Ruiz E, Weidema BP (2016) The ecoinvent database version 3 (part I): overview and methodology. Int J Life Cycle Assess 21(9):1218-1230. https:// doi.org/10.1007/s11367-016-1087-8

Woidasky J, Gasde J, Lang-Koetz C, Moesslein J (2020c) Tracer-Based Sorting als Querschnittstechnologie für die Kreislaufwirtschaft [Tracer-based sorting as a cross-sectional technology for the circular economy]. Thomé-Kozmiensky Verlag GmbH (Recycling und Rohstoffe, 13). Neuruppin. Recycling- und Sekundärrohstoffe - Band 13, 2020, p. 257-266

Woidasky J, Moesslein J, Wendler P, Kirchenbauer D, Wacker D, Gao G, Lang-Koetz C (2020) Kunststoffidentifikation und-sortierung in der Circular Economy durch Fluoreszenzmarker [Plastic identification and sorting in the circular economy using fluorescent markers]. Chemie Ingenieur Technik 92(4):441-451. https://doi. org/10.1002/cite.201900126

Woidasky J, Sander I, Schau A, Moesslein J, Wendler P, Wacker D, Guojun G, Kirchenbauer D, Kumar V, Busko D, Howard IA, Richards BS, Turshatov A, Wiethoff S, Lang-Koetz C (2020) Inorganic fluorescent marker materials for identification of post-consumer plastic packaging. Resour Conserv Recycl 161:104976. https:// doi.org/10.1016/j.resconrec.2020.104976

Publisher's note Springer Nature remains neutral with regard to jurisdictional claims in published maps and institutional affiliations. 